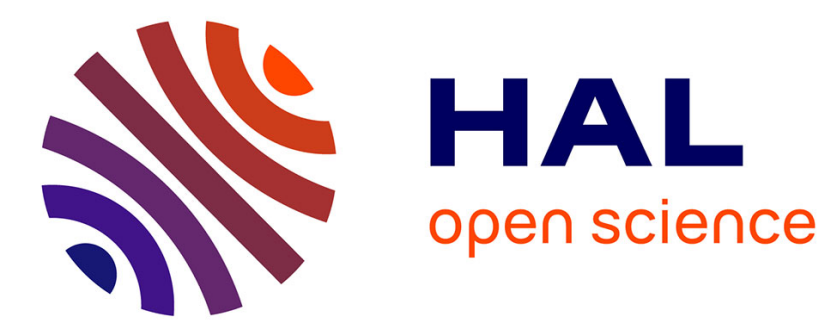

\title{
Evolution of a Late Oxfordian: early Kimmeridgian carbonate platform, French Jura Mountains
}

\author{
Nicolas Olivier, Elsa Cariou, Pierre Hantzpergue
}

\section{To cite this version:}

Nicolas Olivier, Elsa Cariou, Pierre Hantzpergue. Evolution of a Late Oxfordian: early Kimmeridgian carbonate platform, French Jura Mountains. Swiss Journal of Geosciences, 2015, 108 (2-3), pp.273288. 10.1007/s00015-015-0189-9 . hal-02115001

\author{
HAL Id: hal-02115001 \\ https://hal.uca.fr/hal-02115001
}

Submitted on 27 Nov 2021

HAL is a multi-disciplinary open access archive for the deposit and dissemination of scientific research documents, whether they are published or not. The documents may come from teaching and research institutions in France or abroad, or from public or private research centers.
L'archive ouverte pluridisciplinaire HAL, est destinée au dépôt et à la diffusion de documents scientifiques de niveau recherche, publiés ou non, émanant des établissements d'enseignement et de recherche français ou étrangers, des laboratoires publics ou privés. 


\title{
Evolution of a Late Oxfordian: early Kimmeridgian carbonate platform, French Jura Mountains
}

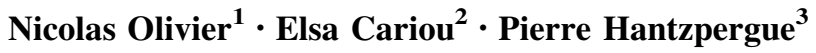

Received: 27 August 2014/Accepted: 27 March 2015/Published online: 23 April 2015

(C) Swiss Geological Society 2015

\begin{abstract}
A detailed facies analysis and interpretation of the evolution of depositional environments along a northsouth transect of the Late Oxfordian-Early Kimmeridgian French Jura carbonate platform highlights hierarchically stacked depositional sequences. The identified small- and medium-scale depositional sequences are matched with the precise cyclostratigraphic framework initially established for the Swiss Jura platform. The superimposition of a longterm (2nd order) sea-level rise with long (400 kyr) eccentricity cycles explains most of the French Jura platform architecture. During the Bimammatum and Planula zones, the climate became progressively warmer and more arid, allowing enhanced carbonate production. This resulted in a strong progradation of the French Jura platform that progressively evolved from a ramp to an oolitic rimmed shelf. A brief interval characterized by a more humid climate
\end{abstract}

Editorial handling: W. Winkler.

Nicolas Olivier

n.olivier@opgc.fr

Elsa Cariou

elsacariou@orange.fr

Pierre Hantzpergue

pierre.hantzpergue@cegetel.net

1 Laboratoire Magmas et Volcans, Université Blaise Pascal, CNRS, IRD, OPGC, 5 rue Kessler, 63038 Clermont-Ferrand, France

2 Laboratoire de Planétologie et Géodynamique de Nantes, Université de Nantes, CNRS UMR 6112, 2, rue de la Houssinière, BP 92208, 44322 Nantes Cedex 3, France

3 Laboratoire de Géologie de Lyon: Terre, Planètes, Environnement, Université de Lyon, CNRS UMR 5276, Université Claude Bernard LYON 1, Campus de la DOUA, Bâtiment Géode, 69622 Villeurbanne Cedex, France during the upper Bimammatum Zone caused an increase in siliciclastic and nutrient input, leading to a reduction in carbonate production and strong retrogradation of the platform. During the Platynota and lower Hypselocyclum zones, the shallow inner shelf carbonate production once more exceeded the accommodation, leading to a general aggradation of the platform. From the upper Hypselocyclum Zone, with a more humid climate, the carbonate production did not outweigh the accommodation creation and the platform evolved to a flat-topped shelf. Thus, sealevel changes and climatic conditions (temperature and humidity) are the key factors controlling the nature of the sedimentation and the depositional profile of the French Jura platform during the Late Oxfordian-Early Kimmeridgian.

Keywords Carbonate platform - Depositional sequence · Depositional environment $\cdot$ Climate $\cdot$ French Jura Moutains · Late Jurassic

\section{Introduction}

The Late Jurassic was a prolific Epoch for carbonate production and widespread carbonate platform construction (Kiessling et al. 2003; Leinfelder et al. 2002). Between the Paris Basin to the northwest and the Ligurian segment of the Mesozoic Tethys to the southeast, extensive shallow carbonate areas constituted the Jura, Lorraine and Swabian platforms (Reinhold 1998; Colombié and Strasser 2005; Carpentier et al. 2010). The growth and demise of these carbonate platforms occurred in various climatic, eustatic and tectonic contexts (Pittet and Strasser 1998; Pittet et al. 2000; Jank et al. 2006a; Carpentier et al. 2006, 2007). Indeed, these 'carbonate factories' were controlled by 
numerous environmental parameters such as water depth, light, nutrient supply, temperature, salinity, hydrodynamic processes, and oxygenation (Lees 1975; Wright and Burchette 1996; Halfar et al. 2006). Late Jurassic carbo nates recorded orbital (Milankovitch) cycles that were responsible for low-amplitude sea-level changes (Strasser 2007; Strasser et al. 1999, 2012). Other factors, apart from sea-level variations, that can affect carbonate production are siliciclastic and nutrient input (Mutti and Hallock 2003; Carpentier et al. 2010). The Late Jurassic generally is thought to have had an equable global climate and warm temperatures (Frakes et al. 1992; Hallam et al. 1993). Nevertheless, several recent studies indicate Late Jurassic climate variations in shallow platform carbonates with short-term sea surface temperature changes in the northwestern Tethys (Dromart et al. 2003a, b; Carpentier et al. 2006; Brigaud et al. 2008; Donnadieu et al. 2011; Dera et al. 2011).

The Late Jurassic Swiss Jura platform has been intensively studied, and a precise sequential and cyclostratigraphic framework has been established (Gygi and Persoz 1986; Gygi 1986; Strasser 1994; Pittet 1996; Strasser et al. 1999, 2000; Colombié 2002; Hug 2003; Jank et al. 2006b). However, these works did not reconstruct a detailed depositional architecture of the Late Jurassic Swiss Jura platform, which is commonly represented by general lithostratigraphic profiles (Gygi et al. 1998; Gygi 2000). In comparison, there are several lithostratigraphic studies for the Late Jurassic French Jura platform available (Enay 1966; Gaillard 1983; Bernier 1984; Enay et al. 1988; Enay 2000), but only one sequential study (Cochet et al. 1994). Thus, the sequential framework of the French Jura platform needs to be improved, especially as correlation with the Swiss Jura is still fragmentary. Moreover, the depositional architecture and the nature of the controlling factors (i.e. tectonic or eustatic) for the French Jura platform are still debated (Cochet et al. 1994). The work presented here gives a detailed sedimentological analysis of 10 sections along a north-south transect of the French Jura platform during the Late Oxfordian-Early Kimmeridgian interval. The aims of this paper are (1) to propose a new scheme of the French Jura platform architecture; (2) to illustrate a common sequential stratigraphic framework between the French and Swiss Jura Mountains; and (3) to decipher the main stages and mechanisms that governed the evolution of the French Jura platform.

\section{Geographical and palaeogeographical settings}

The study area is located in the Jura chain, which is an arcuate fold belt located in front of the western Alpine arc. The 10 studied sections are aligned along a general north-south $151 \mathrm{~km}$ long transect between Besançon and Oyonnax in eastern France (Fig. 1a). Up to the Late Oxfordian-Early Kimmeridgian, the French Jura platform can be subdivided into northern (from Besançon to Champagnole), central (from Champagnole to Saint-Claude) and southern (from Saint-Claude to Belley) palaeogeographical sectors (Enay et al. 1988; Cochet 1995; Cariou 2013). Two sections (Consolation and La Main) are located in the Northern Jura, five in the Central Jura (Mont-Rivel, La Châtelaine, Loulle, Balerne, and Morillon), and three in the Southern Jura (Chancia, Molinges, and Champfromier). During the Late
Fig. 1 a Geographical and b paleogeographical context at the Bimammatum/Planula boundary (Late Oxfordian), compiled after Cecca et al. (2005), Hug (2003), Jank et al. (2006a), and Cariou et al. (2014)
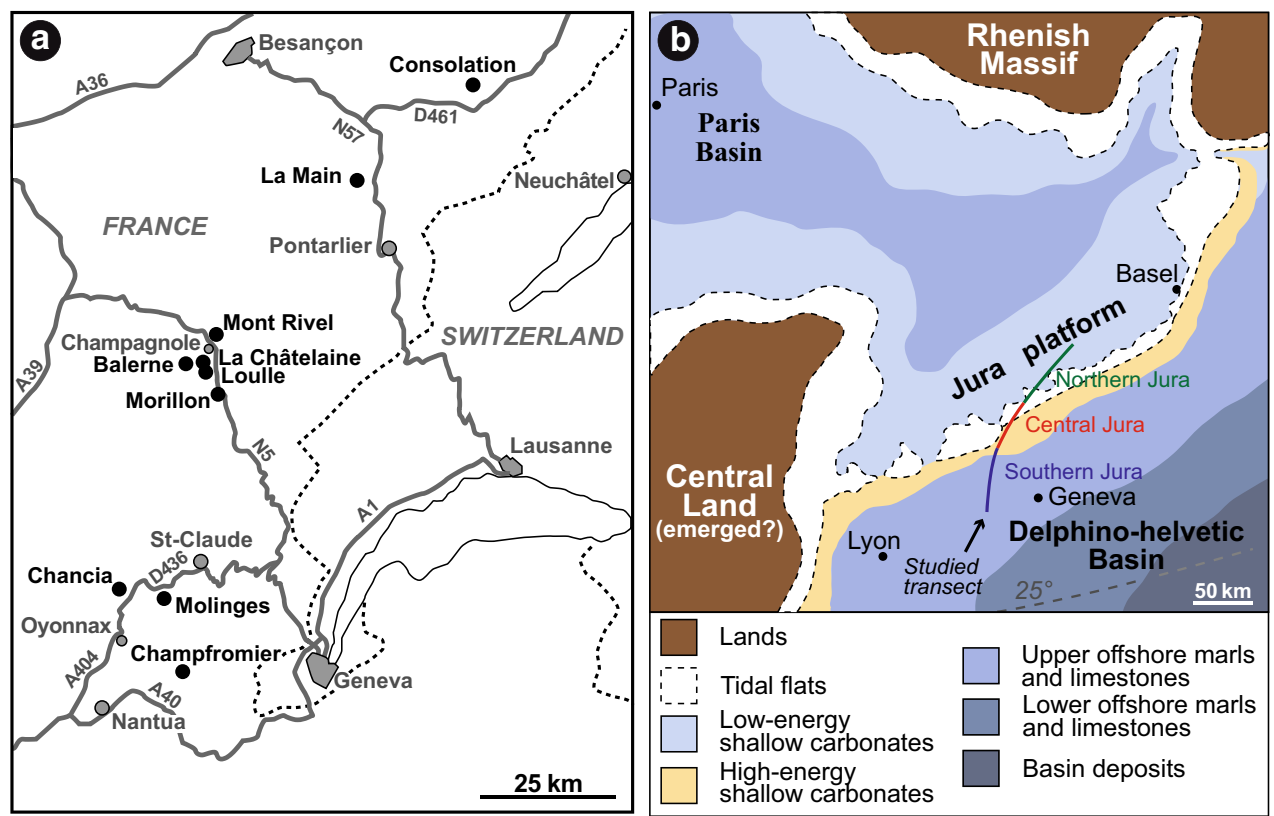
Jurassic, the platform was part of a large shallow epicontinental sea, at the northern margin of the oceanic Ligurian Tethys, between the Paris Basin to the northwest and the Delphino-helvetic Basin to the south (Thierry et al. 2000; Fig. 1b). The Jura platform was at a palaeolatitude of around $26-27^{\circ} \mathrm{N}$, with a climate that was subtropical, semi-arid to arid (Frakes et al. 1992; Dercourt et al. 1993). The platform was at the transition between the Tethyan and boreal realms (Cecca et al. 2005). The sediments deposited on the Jura platform mainly correspond to shallow-water carbonates and marls (Gaillard 1983; Bernier 1984; Cochet 1995; Pittet 1996; Colombié 2002; Hug 2003).

\section{Lithostratigraphy and biostratigraphy}

There have been several attempts to construct a Late Jurassic lithostratigraphic framework for the French Jura Mountains (Bernier 1984; Enay et al. 1988; Chevallier 1989; Cochet et al. 1994). The rarity of ammonites along the French Jura platform explains why the dating of some lithostratigraphic units is still subject to debate (Enay 2000, 2002; Bernier 2002). Along the studied transect, only the Champfromier section-located in the southernmost part of the Southern Jura-displays a detailed biostratigraphic framework from the base of the Planula Zone to the top of the Divisum Zone (Hantzpergue 1975; Cochet 1995). The stratigraphic position of the Molinges section is given in Olivier et al. (2011). For the Central Jura, the stratigraphic position of the Loulle section refers to Cariou et al. (2014). The litho- and biostratigraphic frameworks presented in Table 1, and used for the correlation of studied sections, largely follow the work of Cariou (2013). Only the main lithostratigraphic modifications, with the more recent attempts of Cochet et al. (1994) and Enay (2000), are specified below. Major changes concern the Central Jura sector, where the Couches du Morillon Formation is attributed to the Bimammatum Zone rather than the Planula Zone. This formation groups the Oolithe du Mont Rivel, the Calcaires blancs du Mont Rivel, the Calcaires marneux récifaux de Loulle, and the Calcaires de Loulle members (Cariou 2013). As a consequence, the Central Jura lateral equivalent of the Southern Jura Oolithe de Ramasse (Oolithe de Corveissiat of Bernier 1984; see Enay 2000) Formation is therefore the Oncolithe de Pillemoine Member. Thus, contrary to the work of Cochet et al. (1994), the Central Jura was not emerged during the Platynota and lower Hypselocyclum zones, but recorded the Calcaires d'Aranc Formation and the lower part of the Calcaires et Marnes à ptérocères Formation (Cariou 2013).

Table 1 Litho- and biostratigraphy of the Late Jurassic Jura Mountains
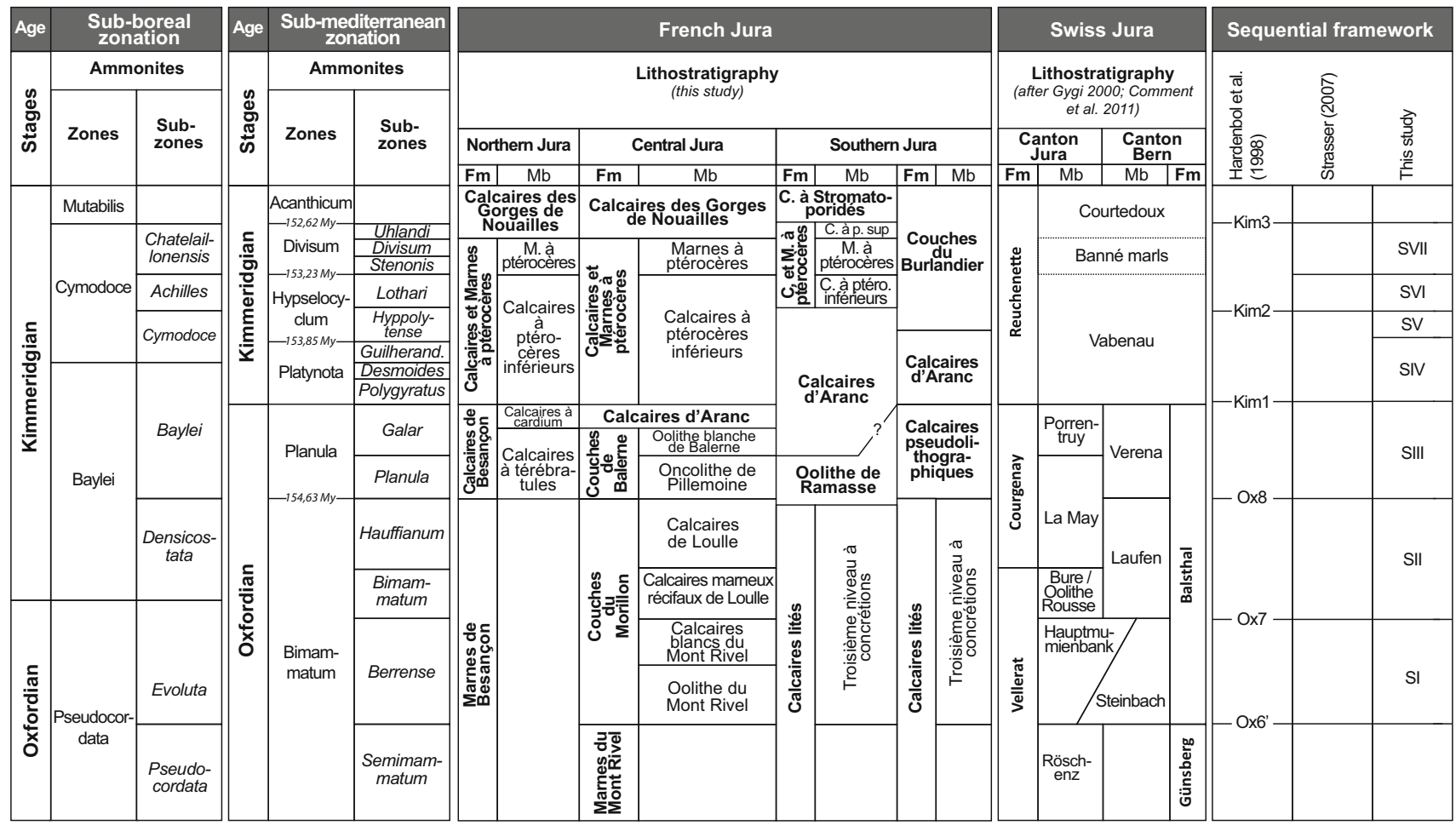


\section{Materials and methods}

The 10 studied sections illustrate a $200 \mathrm{~m}$ thick Upper Oxfordian-Lower Kimmeridgian succession. These sections were logged at bed scale and documented by field observations and by more than 950 polished slabs and 450 thin sections (Cariou 2013). For the beds that were not sampled, facies were analysed in the field with a hand lens. The sedimentary structures were also described in the field. The classification of Dunham (1962) was used to determine textures. The main sedimentary grains and fossil abundances were established using a semi-quantitative estimation (see Cariou 2013). All these sedimentological data were used to interpret the depositional environments. The high-resolution sequence stratigraphic analysis follows the concepts of Strasser et al. (1999). Facies changes and discontinuity surfaces allow different orders of hierarchically stacked depositional sequences to be identified.

\section{Facies and depositional settings}

Based on Cariou (2013), facies are grouped into five facies associations (FA1-FA5), typical of depositional environments ranging from outer shelf to tidal flats (Table 2). Facies association FA1 includes mudstones with marly intercalations (F1.1) and mudstones with thin bioclastic horizons (F1.2). These two facies are observed in the Calcaires pseudolithographiques and Couches du Burlandier formations in the southernmost Jura and in the Calcaires à térébratules Member in the northernmost Jura (Figs. 2, 3). Their mud-supported texture and the presence of ammonites are consistent with deposition in a marine offshore setting (Enay 1966, 2000; Hantzpergue 1975; Gaillard 1983; Bernier 1984; Olivier et al. 2011; Görög and Wernli 2013). Laminated bioclastic horizons of facies F1.2 reflect the influence of distal tempestites at the transition between the lower and upper offshore.

Facies association FA2 encompasses oncoid packstone (F2.1), coral-microbialite patch reefs and biostromes (F2.2), oncoid marls (F2.3), and bioclastic wackestone (F2.4). Facies F2.1-3 are characteristic of several lithostratigraphic members (troisième niveau à concretions, Calcaires marneux récifaux de Loulle, Oncolithe de Pillemoine, and Calcaires à térébratules) and of the Calcaires d'Aranc Formation in the southernmost Jura (Fig. 3). Facies F2.4 is observed in the Calcaires et Marnes à ptérocères Formation. It did not coexist with other facies that constitute FA2. Oncoid packstone (F2.1) and coral-microbialite patch reefs (F2.2) are close to the inner- to midramp transition, whereas coral-microbialite biostromes (F2.2) and oncoid marls (F2.3) were deposited in the central to distal parts of the mid ramp (Olivier et al. 2011).
Mud-supported texture of Facies F2.4 is consistent with deposition below the fair-weather wave base (upper offshore).

Facies association (FA3) corresponds to ooid grainstone (F3.1), ooid-bioclastic grainstone (F3.2), peloid-intraclastic packstone (F3.3), and coral patch reefs (F3.4). These facies are observed in the Oolithe du Mont Rivel and the Oolithe blanche de Balerne members, and in the Oolithe de Ramasse Formation (Fig. 3). Facies F3.1, with grainstone texture, some micritic intraclasts, and local mud drapes, is interpreted as being part of a tidally-influenced shoal complex (Table 2). Facies F3.2, with more abundant bioclasts (i.e. crinoid and bivalve fragments) associated with ooids, may have been deposited on the seaward side of the tide-dominated shoal complex (Halley et al. 1983). Facies F3.3, with abundant intraclasts, coral fragments, oncoids and some gastropods, was deposited in channels that cut across the shoal. Facies F3.4 corresponds to meter-scale coral patch reefs surrounded by ooid grainstones. These bioconstructions are part of the shoal complex.

Facies association FA4 comprises peloid-oncoid packstone (F4.1) and peloid-oncoid packstone with stromatoporoids (F4.2), peloid grainstones (F4.3), bioturbated mudstones (F4.4) and bioclastic packstones (F4.5). Facies F4.1 and F4.3 are observed in the Calcaires blancs du Mont Rivel and Calcaires de Loulle members (Fig. 3). Facies F4.2 and F4.3 are characteristic of the Calcaire à Cardium Member and the Calcaire d'Aranc Formation. Facies 4.5 is observed in the Calcaires et Marnes à ptérocères Formation. It did not coexist with other facies that constitute FA4. Facies F4.1 and F4.2 are both characterized by large oncoids with cortices made of Lithocodium and Bacinella (oncoid types 3 and 4 of Védrine et al. 2007). Facies F4.2 is characterized by abundant stromatoporoids of the genus Cladocoropsis, which are classically observed in shallow lagoon and inner ramp settings (Leinfelder et al. 2005). Facies F4.1 and F4.2 are here interpreted as deposits of back shoal settings. Facies F4.3, with grain-supported texture and abundant peloids, represents small back shoal bars. Facies F4.4, with mud-supported texture and abundant infaunal activity, reflects low-energy internal platform deposition. Facies F4.5, with fauna observed in life position and packstone (locally grainstone) texture, is interpreted as deposits of a low-energy shoreface setting (Table 2).

Facies association FA5 contains three facies (F5.1-F5.3) characteristic of tidal flats (Cariou 2013). Facies F5.1 is observed in the Calcaires de Loulle Member. Facies F5.2 and F5.3 are observed in the Calcaires d'Aranc Formation (Fig. 3). Facies F5.1 corresponds to biolaminites that record dinosaur tracks (Cariou et al. 2014). Facies F5.2 corresponds to a finely laminated mudstone with intense infaunal activity and some desiccation cracks. Facies F5.3 


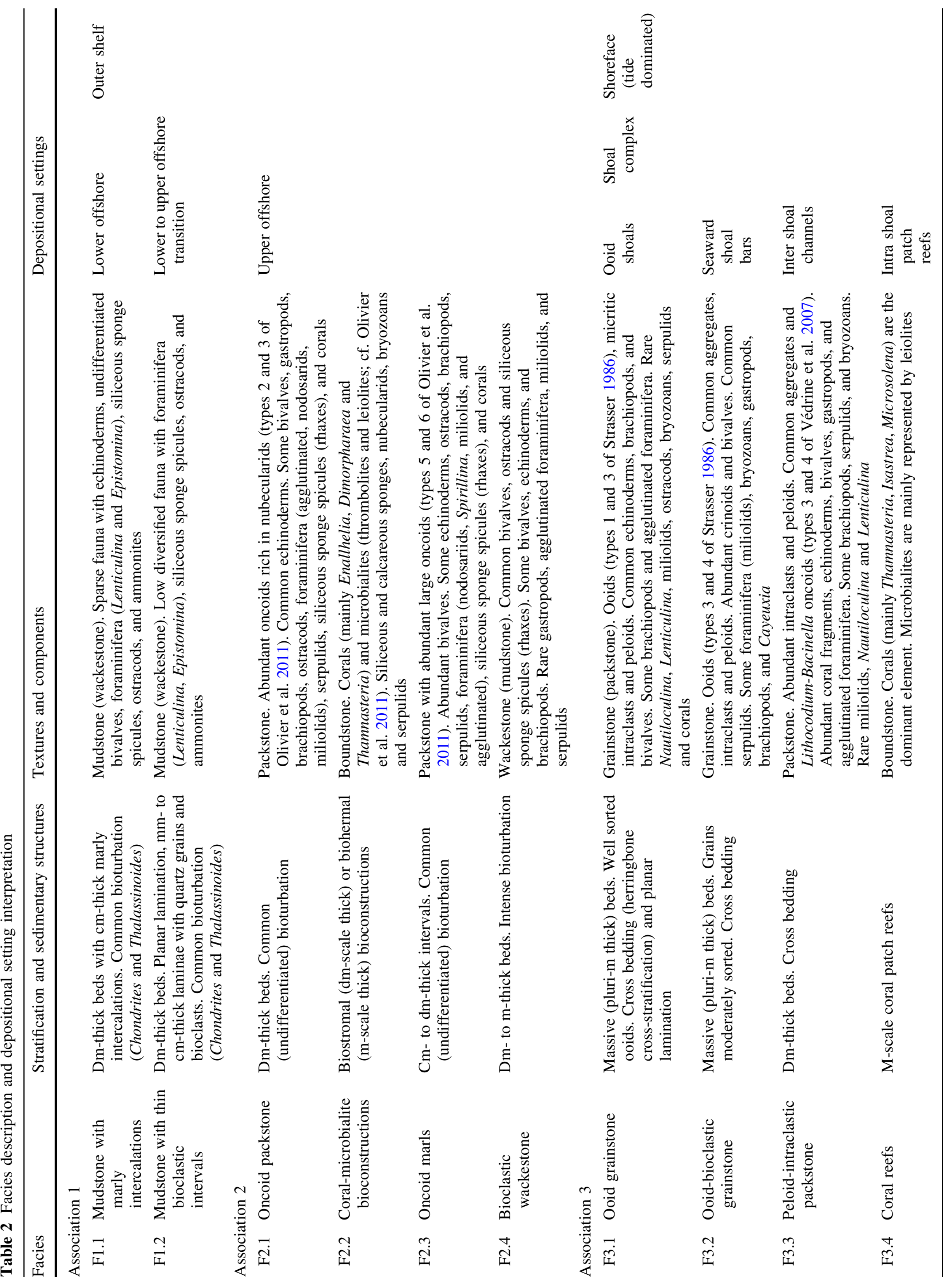




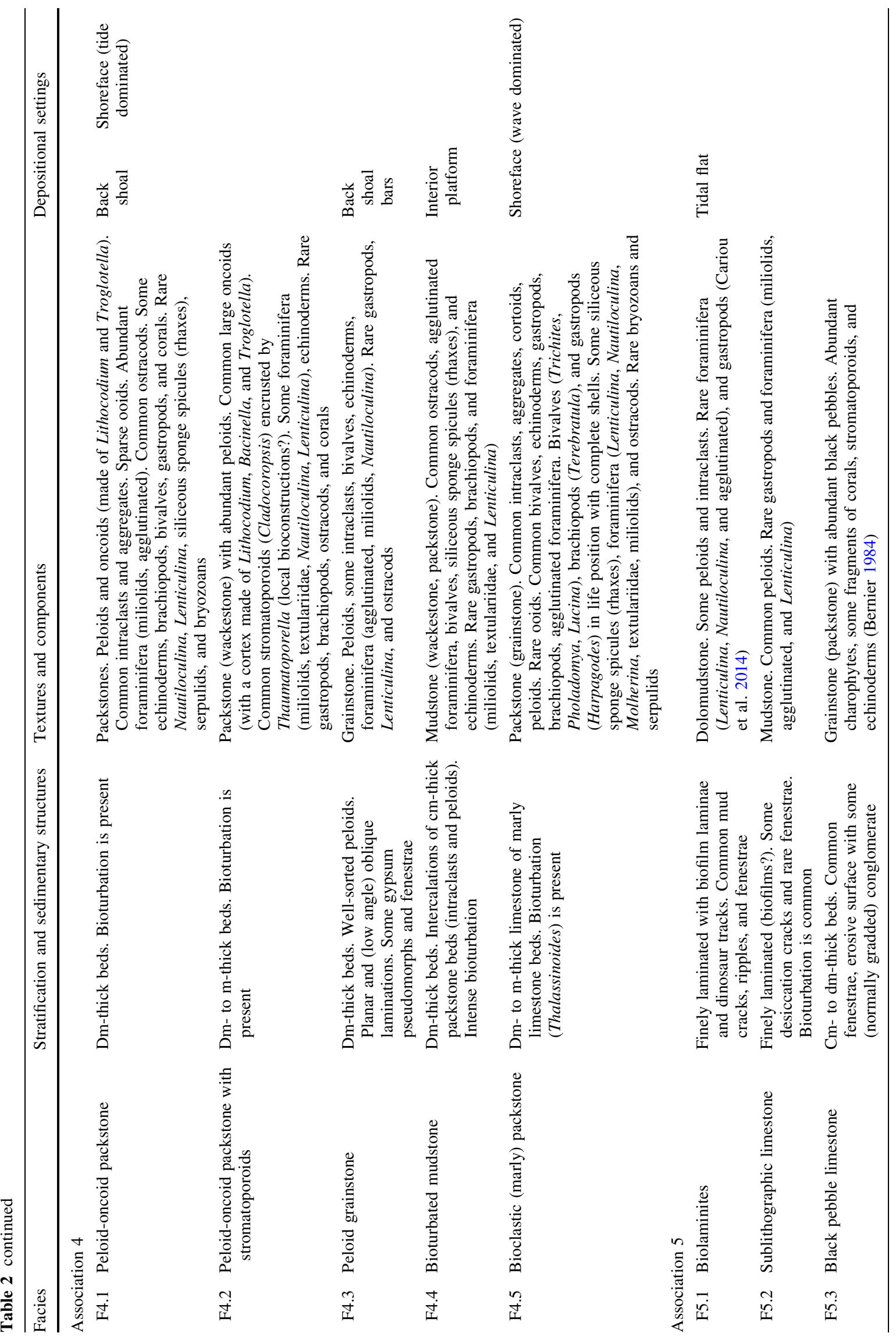


corresponds to a black pebble limestone, suggesting phases of emersion (Strasser 1984; Bernier 1984).

\section{Depositional sequences, facies models and sequential interpretation}

Previous studies carried out on French Late Jurassic sedimentary successions show distinct hierarchical stacking patterns and facies evolution that allow large-, medium-, small-, very-small scale, and elementary depositional sequences to be identified (Olivier et al. 2011; Cariou 2013; Cariou et al. 2014). The inhomogeneous outcrop quality of studied sections coupled to the influence of autocyclic processes that are common in shallow-marine settings make it difficult to correlate the elementary and very small-sequences (Cariou 2013). Figure 3 shows an attempt to correlate studied sections based on small- and medium-scale depositional sequences. Examples of a detailed description of small-scale sequences can be found in Olivier et al. (2011) for the Molinges section and Cariou et al. (2014) for the Loulle section. The following description only considers medium-scale sequences (SISVII).

The first medium-scale sequence (SI) is observed in both the Central Jura and in the northernmost part of the Southern Jura. In the Central Jura, the sharp installation of ooid grainstones (F3.1) above inner shelf marly limestones of the Marnes de Besançon Formation marks the increasing accommodation trend of SI. The progressive progradation of peloid-oncoid packstone (F4.1) documents the decreasing accommodation trend of SI. In the Southern Jura, the increasing accommodation trend of SI is recorded by the deposition of oncoid marls (F2.3). The decreasing accommodation trend of SI corresponds to the deposition of oncoid packstone (F2.1) and coral-microbialite bioconstructions (F2.2; Olivier et al. 2011). The second medium-scale sequence (SII) is still clearly visible in the Central Jura where the retrogradation of coral-microbialite bioconstructions (F2.2) over ooid-bioclastic grainstone (F3.2) marks the increasing accommodation trend of SII. The progradation of peloid-oncoid packstone (F4.1) and the incursion of dinosaurs in the Central Jura highlights the decreasing accommodation trend of SII. In the Southern Jura, the increasing accommodation trend of SII corresponds to coral-microbialite bioconstructions (F2.2) and oncoid packstone (F2.1). The decreasing accommodation trend is marked by the progradation of ooid grainstone (F3.1). The facies observed in the first two depositional sequences (SI and SII) are part of a first depositional model (Fig. 4a). In this model, shoreface deposits correspond to (1) an ooid shoal (F3.1) with small coral patch reefs (F3.4); (2) a back shoal area with peloid- oncoid packstone (F4.1) and peloid bars (F4.3); and (3) a tidal flat with dinosaur tracks (F5.1). Upper offshore deposits correspond to oncoid packstone (F2.1), coral-microbialite bioconstructions (F2.2) and oncoid marls (F2.3). Lower offshore deposits correspond to limestones with marly intercalations (FA1) of the Calcaires lités Formation (Olivier et al. 2011).

The third medium-scale sequence (SIII) can be followed from the Northern to the Southern Jura. Thick ooidal deposits (Oolithe de Ramasse Formation) observed in the northernmost part of the Southern Jura (Chancia and Molinges sections) display an aggradational pattern that is consistent with the increasing accommodation trend of SIII. The decreasing accommodation trend of SIII is emphasized by the progradation of peloid-oncoid packstone (F4.2). Tidal flat deposits (F5.2) recorded in the northernmost part of the Southern Jura mark the top of SIII. The fourth and fifth medium-scale sequences (SIV and SV) are characterized by a general aggradational pattern. In the Northern and Central Jura, SIV and SV are represented by interior platform mudstones (F4.4) that display a progradational pattern towards the south, emphasizing decreasing accommodation trends of these sequences. Facies observed in the medium-scale sequences SIII to SV are part of a second depositional model (Fig. 4b). This model is still characterized by an important tidal dominated shoal complex with the deposition of ooid grainstone (F3.1). Seaward of this shoal complex, mid-shelf deposits are characterized by oncoidal and bioclastic deposits (F2.1). Back shoal deposits correspond to oncoid packstone with stromatoporoids (F4.2), peloid bars (F2.3), and shallow interior platform mudstones (F4.4). Emergent areas are restricted to local islands probably generated by the growth of microbial mats (F5.2) on the interior of the platform.

The sixth medium-scale depositional sequence (SVI) marks a general accommodation gain over the entire Jura platform with the deposition of bioclastic wackestone (F2.4). With a general aggradational pattern, the increasing accommodation trend of SVI corresponds to the evolution from grain-supported to mud-supported texture. A thin interval of bioclastic packstone (F4.5), only recorded in the Central Jura, marks the decreasing accommodation trend of SVI. The seventh medium-scale depositional sequence (SVII) is incompletely recorded along the studied area. Nevertheless, the increasing accommodation trend is also marked by the general evolution from bioclastic packstone (F4.5) to bioclastic wackestone (F2.4) with some incursions of mudstone (FA1) from the Southern Jura to the Central Jura. The decreasing accommodation trend of SVII is beyond the scope of the present study but corresponds to the deposition of grain-supported limestones of the Calcaires des Gorges de Nouailles Formation in Northern and Central 
Fig. 2 Legend for Figs. 3, 4 and 5

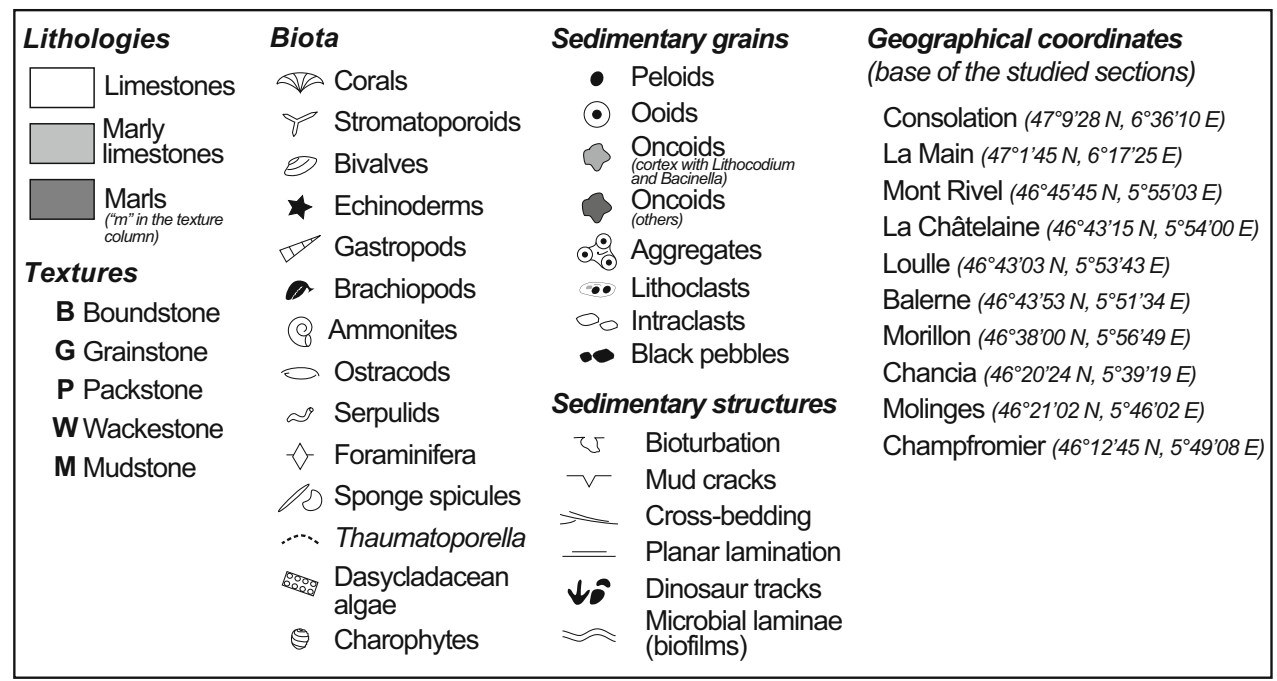

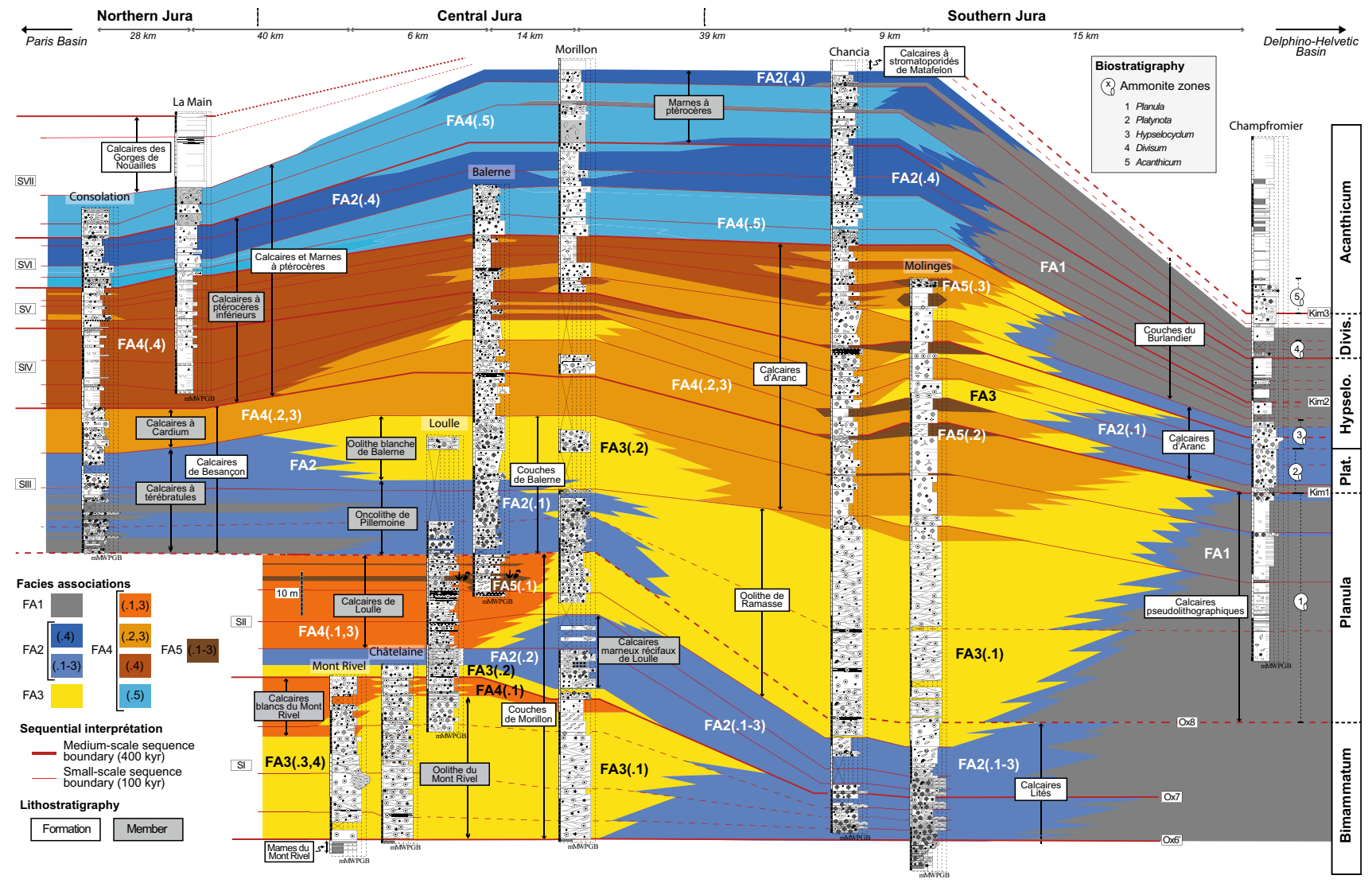

Fig. 3 Correlation of sections and depositional sequences. The numbered medium-scale sequences (SI-SVII) are interpreted to correspond to the 100-kyr eccentricity cycle. Sequence boundaries

Jura, and the Calcaires à stromatoporidés de Matafelon Formation in the Southern Jura. Facies observed in SVI and in the lower part of SVII are part of a third depositional model (Fig. 4c). In this model, the Jura platform
Ox6 $6^{\prime}$ to Kim 3 according to Hardenbol et al. (1998). Geographical coordinates of sections are in Fig. 2

corresponds to a large epeiric system, in which the distribution of the facies belts is consistent with a non-rimmed shelf. The large extension of shallow settings could have significantly damped the hydraulic energy of waves, 

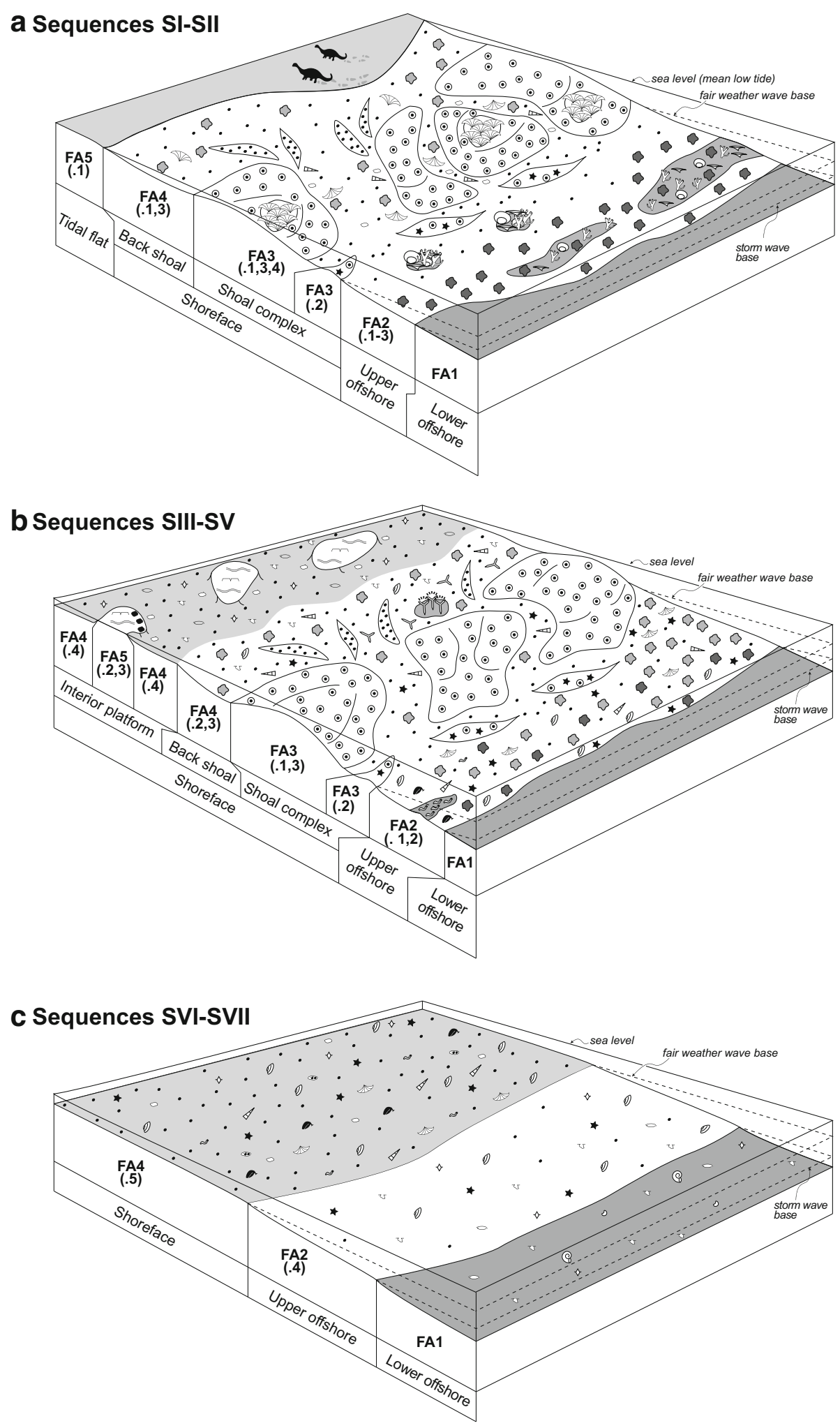

Fig. 4 Facies models. Not to scale

explaining the deposition of mud in a mainly grain-supported fabric (F4.5) even in zones where wave friction would generally impact the sea floor. Below the fair- weather wave base, sediments correspond to bioclastic wackestone (F2.4), whereas lower offshore deposits are represented by mudstone with ammonites (FA1). 
Numerous studies have been carried out on the Late Jurassic deposits of the Swiss Jura Mountains leading to a precise sequential and biostratigraphic framework (Pittet 1996; Gygi 2000; Hug 2003; Jank et al. 2006a, b; Colombié and Rameil 2007; Strasser 2007). Lithostratigraphic and biostratigraphic frameworks obtained for the French Jura Mountains allow a comparison to be made with the Swiss Jura and the sequence-chronostratigraphic chart of Hardenbol et al. (1998) (Table 1; Fig. 3). Thus, the lower boundary of medium-scale depositional sequences SII, SIII, SIV, and SVI can be tentatively correlated with sequence boundaries Ox7, Ox8, Kim1, and Kim2, respectively. The lower boundary of SI can be correlated with Ox6' (Hug 2003; Védrine et al. 2007) and the upper boundary of SVII corresponds to Kim3. The cyclostratigraphic interpretation given by Strasser (2007) suggests that the durations of the Swiss depositional sequences correspond to orbital frequencies. Applied to the studied French Jura sections, this sequence-chronostratigraphic framework leads us to consider that the small- and medium-scale sequences SI-SVII were formed by the 100- and 400-kyr orbital cycles of eccentricity, respectively.

\section{French Jura platform evolution and controlling factors}

The evolution of the French Jura platform during the Late Oxfordian-Early Kimmeridgian can be subdivided into 6 main stages (Fig. 5). The first stage corresponds to the first medium-scale depositional sequence, SI, during the $\mathrm{Bi}$ mammatum Zone (Stage 1, Fig. 5). According to Strasser et al. (2012), the climate evolution of the Jura platform during this time-interval was marked by a cooling trend. In the French Central Jura, the sharp installation of ooid deposits and coral reefs (Oolithe du Mont Rivel Member) does not point to cool seawater temperatures. Indeed, both corals and ooids are very rare or absent at temperatures below $20^{\circ} \mathrm{C}$, and the optimal conditions for coral development occur between 24 and $28{ }^{\circ} \mathrm{C}$ (Lees 1975; Tucker and Wright 1990). Rather than a putative control by temperature, the initiation of the carbonate production in the French Central Jura could be explained by a change in terrigenous input. Humidity changes in the hinterland influence the terrigenous influx, which modifies the water's trophic level (Mutti and Hallock 2003). For the Swiss Jura platform, the climate is considered to have become less humid above Ox6' (Pittet 1996; Hug 2003; Védrine 2007; Strasser et al. 2012). Such a climate change may have favoured the formation of ooids and coral reefs on the inner shelf marly limestone of the Marnes de Besançon Formation. The installation of these shallow, high-energy deposits could also have been favoured by a position above a hypothetical NE-SW oriented axial swell (Enay et al. 1988; Cochet et al. 1994). Moreover, the first stage of development of the French Jura platform occurred during a sea-level rise both at the second order (Hardenbol et al. 1998) and medium-scale cycle Ox6' (Hug 2003; Védrine et al. 2007; Olivier et al. 2011). In the Central Jura, this sea-level rise generated sufficient accommodation gain to accumulate the thick ooid interval, the Oolithe du Mont Rivel Member, on a carbonate platform that probably displayed a ramp profile (Cochet et al. 1994). A sea-level fall at the scale of the medium-scale sequence SI controlled the progradation of back shoal deposits of the Calcaires blancs du Mont Rivel Member. Deposits observed in the Central Jura notably correspond to inner ramp ooids, corals, and oncoids with a cortex made of Lithocodium, which reflect well-oxygenated, well-agitated, oligotrophic conditions (Schmid and Leinfelder 1996; Dupraz and Strasser 1999; Shiraishi and Kano 2004; Lefort et al. 2011; Olivier et al. 2012). In the Southern Jura, the presence of oncoids devoid of photo- and oligotrophic encrusters associated with mixed photo-heterotrophic coral assemblages indicates more nutrient-rich conditions in a mid ramp setting (Olivier et al. 2011).

The second stage of the French Jura platform growth occurred during the increasing accommodation trend of medium-scale sequence SII (Stage 2, Fig. 5). This stage is characterized by a large extension of mid-ramp deposits over the northernmost part of the Southern and Central Jura. These deposits notably correspond to small-size bioconstructions composed of mixed photo-heterotrophic coral assemblages and abundant microbialites, which emphasize mesotrophic conditions (Olivier et al. 2011; Cariou 2013; Cariou et al. 2014). The last record of siliciclastic inputs onto the Jura platform is known to have occurred sporadically in the upper part of the Bimammatum Zone (Gygi 1986; Pittet 1996; Pittet and Strasser 1998; Hug 2003). The presence of marly limestones in the Central Jura is consistent with a climate that became temporarily more humid during SII (Pittet 1996; Hug 2003; Strasser et al. 2012). Even if an inner ramp shoal complex might have migrated towards the north (Fig. 3), the carbonate production seems to have been reduced during this second stage. Indeed, nutrients linked to terrigenous inputs can limit coral growth and the formation of ooids (Hallock and Schlager 1986; Leinfelder 1993; Pittet 1996). As the upper Bimammatum Zone is still characterized by a seawater temperature increase (Brigaud et al. 2008; Martin-Garin et al. 2010), more nutrient-rich waters coupled to the sea-level rise of SII led to an important retrogradation of the French Jura platform, which still displayed a ramp profile.

The third stage of the French Jura platform growth occurred during the decreasing accommodation trend of medium-scale sequence SII (Stage 3, Fig. 5). The upper 
Stage 6 Platform retrogradation - SVI and SVII (pro parte) - upper Hypselocyclum and lower Divisum zones

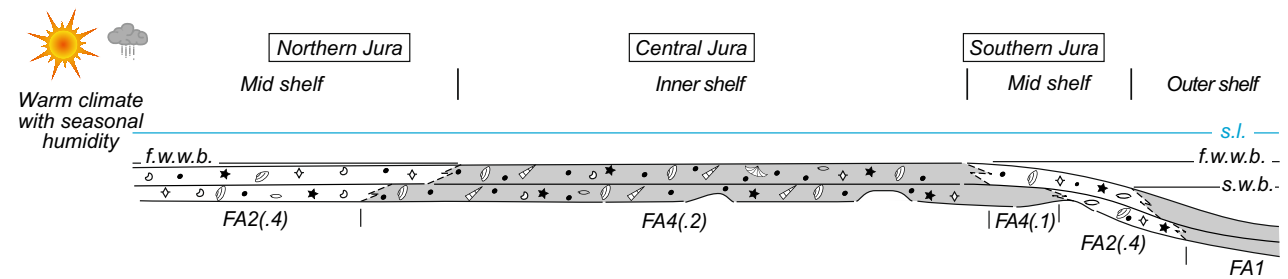

Stage 5 Shelf aggradation - SIV and SV - Platynota and lower Hypselocyclum zones

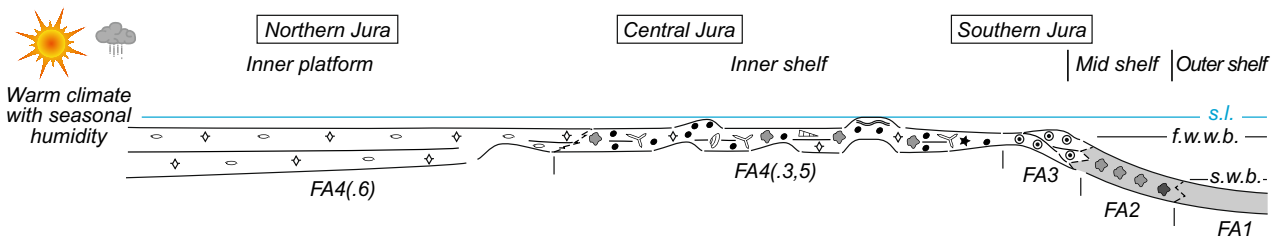

Stage 4 Shelf aggradation and progradation - SIII - Planula Zone

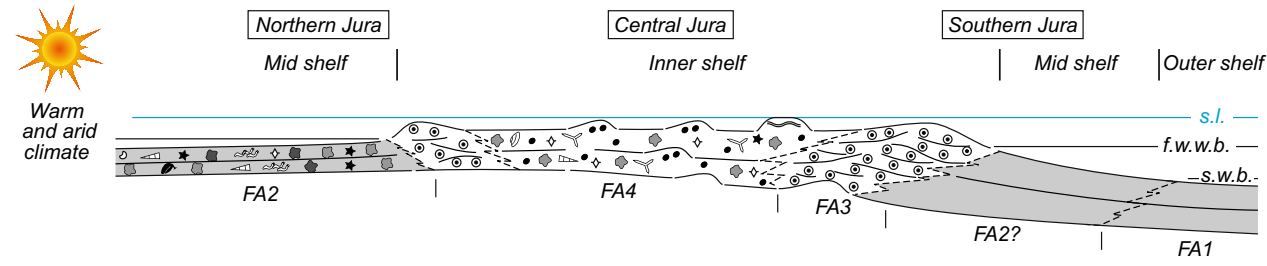

Stage 3 Ramp progradation - Decreasing accommodation trend of SII - Bimammatum Zone

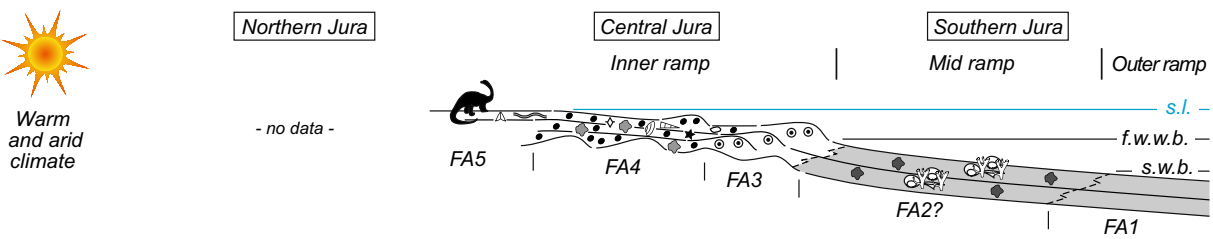

Stage 2 Ramp retrogradation - Increasing accommodation trend of SII - Bimammatum Zone
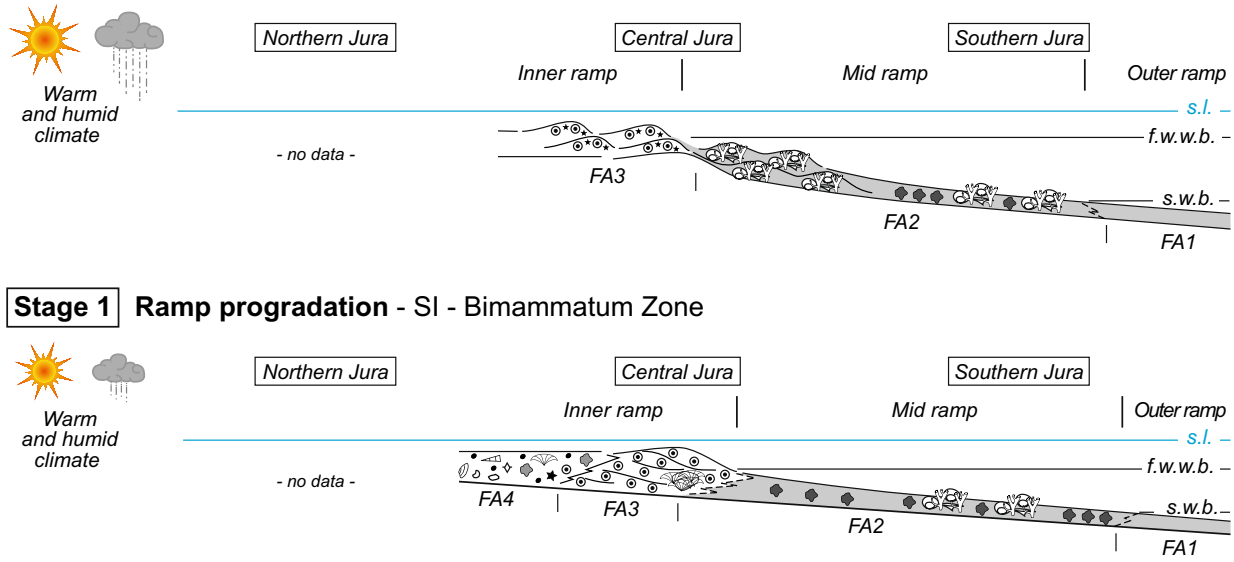

Fig. 5 French Jura platform evolution. Not to scale

Bimammatum Zone is characterized by the installation of a warm, arid climate (Strasser et al. 2012). The Burgundy platform recorded the temperature maximum during the
Bimammatum Zone, although inputs of freshwater, characterized by low $\delta^{18} \mathrm{O}$ values, may have led to a decrease in carbonate $\delta^{18} \mathrm{O}$ values as well and thus to an 
overestimation of the calculated isotopic temperatures (Carpentier et al. 2006; Martin-Garin et al. 2010). Under a relatively warm climate, and with a reduced amount of terrigenous flux, this third stage reflects favourable conditions for enhanced carbonate production. The French Central Jura records the establishment of a new ooid shoal. In a back shoal position, some of the oncoids still display a thick cortex made of Lithocodium, signifying shallow, well-agitated waters and good light conditions. The return to oligotrophic conditions related to the sea-level fall of SII allowed carbonate production to exceed the available space. This explains the strong progradation of ooid deposits towards the Southern Jura (Fig. 3). It also permitted the progradation of back shoal and tidal flat deposits with their abundant dinosaur tracks into the Central Jura. The presence of these tracks in the uppermost part of the Bimammatum Zone is the earliest record of a dinosaur incursion on the Jura platform during the Late Jurassic (Cariou et al. 2014).

The fourth stage of the French Jura platform growth occurred during the medium-scale sequence SIII (Stage 4, Fig. 5). This sequence is assigned to the Planula Zone, which is characterized by a warm, dry climate (Pittet et al. 2000; Strasser et al. 2012). Such climate conditions allowed intense carbonate production and the progradation of an ooid shoal-rimmed shelf that dipped gently both northwards and southwards. The retrogradation of the oncoid packstone of the Oncolithe de Pillemoine Member in the northern part of the Central Jura suggests an accommodation creation that was partially triggered by tectonics. On the other hand, the platform progradation towards the south can be explained by a carbonate production that exceeded the available space. This fourth stage of platform growth is characterized by a large extension of shallow inner shelf carbonates over the entire Central Jura and the northernmost part of the Southern Jura (Fig. 3). Inner shelf deposits correspond to oncoid packstone rich in Cladocoropsis. While some stromatoporoid taxa might have tolerated slightly higher salinities (Leinfelder et al. 2005), the presence of some corals and common oncoids with Lithocodium and Bacinella indicates prevailing oligotrophic marine conditions. In the Central and Northern Jura, mid-shelf deposits are still characterized by oncoids that display a cortex made of Lithocodium and Bacinella and by some corals. This suggests the presence of nutrientdepleted waters up to a mid-shelf position. The presence of marly intercalations and rare quartz observed in an outer shelf setting suggests more nutrient-rich waters in a distal part, below the storm wave base. During the sea-level fall of SIII, available space was completely filled by inner shelf deposits, leading to the record of tidal flat settings in the upper part of the Planula Zone. After the dinosaur incursion at the end of the Bimammatum Zone, this is the second occurrence of emersive deposits along the French Jura platform that had strongly prograded towards the south.

The fifth stage of the French Jura platform growth occurred during the medium-scale sequences SIV and SV (Stage 5, Fig. 5). At the base of the Platynota Zone, Lefort (2011) observed a small decrease in calculated isotopic temperatures in the Lorraine-Champagne platform. Brigaud et al. (2008) also indicated a small decrease in calculated isotopic temperatures in the Lorraine platform between the Platynota and Hypselocyclum zones. From Kim1, Colombié (2002) indicates a semi-arid climate with relatively well-developed humid seasons for the Swiss Jura platform. In the Northern French Jura platform, an increase in quartz content is observed in deposits of the Calcaires à pétrocères inférieurs Member (Cariou 2013). This confirms a greater terrigenous influx from the hinterland and thus a climate with a rainy season during the fifth stage. More nutrient-rich conditions might explain sparser occurrences of ooid limestones along the French Jura platform during the Platynota and lower Hypselocyclum zones (Fig. 3). Combined with the installation of a more humid climate, the Early Kimmeridgian in the Central Swiss Jura is also characterized by a general loss of accommodation (Colombié 2002; Colombié and Strasser 2005). These authors suggest that a slowing down of the 2nd order sealevel rise coupled with an adequate carbonate production allowed sedimentation to keep up with sea-level rise. During the Platynota and lower Hypselocyclum zones, the French Jura platform reached maximum extent with midshelf oncoid limestones in the southernmost Jura (Fig. 3). From the northern part of the Southern Jura up to the Northern Jura, shallow inner platform sediments built up close to sea level, locally filling available space as indicated by tidal flat deposits. This general aggradational pattern emphasizes a change in the platform profile that evolved into a flat-topped shelf.

The sixth stage of the French Jura platform growth occurred during the medium-scale sequences SVI and SVII pro parte (Stage 5, Fig. 5). This stage is characterized by the retrogradation of mid-shelf deposits over the French Jura platform during the upper Hypselocyclum Zone. This pattern may reflect a long-term maximum flooding that occurred during the Hypselocyclum and Divisum zones (Contini and Hantzpergue 1973, 1975; Hantzpergue 1975; Cochet et al. 1994). Such retrogradation was also favoured by the flat-topped shelf topography established during the Panula Zone. Indeed, flat-topped carbonate platforms are highly sensitive to low-amplitude relative sea-level fluctuations, leading to the deposition of widespread and nearly synchronous beds similar in lithology and stacking pattern (Strasser et al. 1999; Jank et al. 2006c). Phases of retrogradation that occurred during the Hypselocyclum and Divisum zones emphasize a carbonate production that 
could not keep pace with the generated accommodation. A decrease in carbonate production could be explained by an increase in terrigenous input, which is consistent with a semi-arid climate with humid seasons up to the Divisum Zone observed for the Swiss Jura platform (Colombie 2002). More nutrient-rich conditions are documented by the heterotrophic fauna observed in deposits of the Calcaires et Marnes à ptérocères Formation (Table 2). The large extension of a flat inner shelf could have significantly reduced storm-induced waves and currents, accounting for the lack of high-energy deposits.

Thickness variations in Upper Jurassic sedimentary successions in the Swiss Jura Mountains are related to the synsedimentary reactivation of Permo-Carboniferous basement structures (Pittet 1996; Allenbach 2002; Wetzel et al. 2003; Jank et al. 2006a). The influence of a hypothetical NE-SW oriented axial swell has also been invoked as a facies control for the French Jura platform development (Enay et al. 1988; Cochet et al. 1994). However, the present does not support a major structural influence. Instead, it supports a control by variations in the carbonate production in tune with sea-level and climatic changes. Indeed, the Upper Jurassic sedimentary succession of the French Jura Mountains has revealed that the hierarchical stacking pattern of depositional sequences can be explained by the superposition of different orders of sea-level fluctuations (Olivier et al. 2011; Cariou et al. 2014). During the Late Oxfordian-Early Kimmeridgian interval, the different sedimentary bodies observed on the French Jura platform appear to have been formed in tune with a long-term (2nd order) sea-level rise coupled to eccentricity (400 kyr) cycles. Cariou et al. (2014) suggest that a $2.4 \mathrm{Myr}$ cycle may have played a preponderant role in the subsequent incursions of dinosaurs onto the Jura platform. The regressive trend of the $2.4 \mathrm{Myr}$ cycle, which includes the dinosaur track site of Loulle, ends around Kim1. In this scenario the general flat top morphology and successive emergent surfaces observed at the end of SIII could be characteristic of a highstand system within the $2.4 \mathrm{Myr}$ cycle.

The successive stages of the French Jura platform growth also highlight the major role played by climatic conditions. The studied time-interval is effectively marked by a general and long-term climate-warming trend from the Early Oxfordian to the Kimmeridgian (Riboulleau et al. 1998; Abbink et al. 2001). Along with it, the climate became progressively less humid (Védrine 2007; Strasser et al. 2012), leading to warm, oligotrophic waters on the Jura platform. Such environmental conditions allowed intense carbonate production, as illustrated by the development of large ooid shoal complexes in the Central Jura during the Bimammatum Zone or in the Southern Jura during the Planula Zone. Such intense carbonate production was able to change the shelf morphology, which progressively evolved from a ramp to a shoal-rimmed shelf. Periods characterized by a notably more humid climate also had an impact on the nature of the sedimentation and on the platform growth. Thus a more humid climate led to the increase in the amount of terrigenous and nutrient input from the hinterland. Under more nutrient-rich conditions, the carbonate production decreased and when the platform was subjected to a rise in sea-level, it caused major phases of retrogradation (cf. Stages 2 and 6, Fig. 5).

\section{Conclusions}

This study provides a detailed sedimentological analysis of an Upper Oxfordian-Lower Kimmeridgian succession along the French Jura platform. Facies evolution and the correlation of ten studied sections emphasize hierarchically stacked depositional sequences. The resulting sequential framework reveals small- and mediumscale depositional sequences that formed in tune with orbital cycles of short (100 kyr) and long (400 kyr) eccentricity, as had been previously established for the Swiss Jura platform.

The detailed analysis of sedimentary deposits permitted the identification of 5 main facies associations characteristic of depositional environments ranging from outer platform to tidal flat settings. Spatio-temporal evolution of facies along the platform has led to the reconstruction of three successive facies models, and to the subdivision of the platform development into six main stages. Throughout these stages, the profile of the platform progressively evolved from a ramp during the Bimammatum Zone, to an ooid shoal-rimmed shelf during the Planula and lower Hypselocyclum zones, and finally to a flat-topped shelf up to the lower Divisum Zone.

The French Jura platform evolution was directly controlled by the superimposition of different orders of sea-level fluctuations. Most of the sedimentary body geometries were triggered by the 400-kyr long eccentricity cycle superimposed onto a long-term (2nd order) sea-level rise. On two occasions the carbonate accumulation largely exceeded sealevel rise, leading to the subaerial exposure of part of the platform. At the end of the Bimammatum Zone, tidal flat deposits with dinosaur tracks were recorded in the French Central Jura. This is the first Late Jurassic dinosaur incursion onto the Jura platform. During the Platynota and lower Hypselocyclum zones, tidal flat deposits were recorded on the northern part of the Southern Jura, highlighting the strong progradation of the French Jura platform.

The platform evolution and the nature of the sedimentation were also strongly dependent on the climatic conditions, notably in terms of temperature and humidity 
variations. During the Bimammatum and Planula zones, the climate became progressively warmer and arid. Resulting oligotrophic conditions gave rise to enhanced carbonate production on the shallow platform, notably during the middle Bimammatum and Planula zones. During the upper Bimammatum Zone and the lower Hypselocyclum to lower Divisum zones, a climate with humid seasons was responsible for increased siliciclastic and nutrient input. This led to a decrease in carbonate production, and consequent strong retrogradation of the platform, enhanced by a rise in sea-level.

Acknowledgments This project was funded by the Franche-Comté regional council, the Jura departmental council, the municipality of Loulle, and the UMR CNRS 5276 LGL. We are grateful to Cédric Carpentier for his pertinent remarks on a previous version of this manuscript. We gratefully acknowledge Claude Colombié, Raymond Énay and Bernard Pittet for numerous discussions on French and Swiss Jura platforms. We thank Fran van Wyk de Vries for reviewing the English of this manuscript. Thanks to Beatriz Bádenas and Oliver Kempf for their reviews of the manuscript.

\section{References}

Abbink, O., Targarona, J., Brinkhuis, H., \& Visscher, H. (2001). Late Jurassic to earliest Cretaceous palaeoclimatic evolution of the southern North Sea. Global and Planetary Change, 30, 231-256.

Allenbach, R. P. (2002). The ups and downs of "tectonic quiescence"; recognizing differential subsidence in the epicontinental sea of the Oxfordian in the Swiss Jura Mountains. Sedimentary Geology, 150, 323-342.

Bernier, P. (1984). Les formations carbonatées du Kiméridgien et du Portlandien dans le Jura méridional, stratigraphie, micropaléontologie sédimentologie. Documents du Laboratoire de Géologie de Lyon, 92, 1-883.

Bernier, P. (2002). Commentaire à la note : "Une faune d'ammonites inédite du Kimméridgien inférieur à Molinges (Jura) et la limite Oxfordien-Kimméridgien dans le faisceau externe du Jura méridional par R. Enay". Géologie de la France, 3, 60-61.

Brigaud, B., Pucéat, E., Pellenard, P., Vincent, B., \& Joachimski, M. M. (2008). Climatic fluctuations and seasonality during the Late Jurassic (Oxfordian-Early Kimmeridgian) inferred from \& \#x03B4;180 of Paris Basin oyster shells. Earth Planetary Science Letters, 273, 58-67.

Cariou, E. (2013). La plateforme jurassienne au passage OxfordienKimméridgien : dynamique sédimentaire et paléoenvironnements. Ph.D. dissertation, Université Claude Bernard Lyon 1, Villeurbanne, France (pp. 337).

Cariou, E., Olivier, N., Pittet, B., Mazin, J.-M., \& Hantzpergue, P. (2014). Dinosaur track record on a shallow carbonate-dominated ramp (Loulle section, Late Jurassic, French Jura). Facies, 60, 229-253.

Carpentier, C., Lathuiliere, B., \& Ferry, S. (2010). Sequential and climatic framework of the growth and demise of a carbonate platform: implications for the peritidal cycles (Late Jurassic, North-eastern France). Sedimentology, 57, 985-1020.

Carpentier, C., Lathuiliere, B., Ferry, S., \& Sausse, J. (2007). Sequence stratigraphy and tectonosedimentary history of the Upper Jurassic of the Eastern Paris Basin (Lower and Middle Oxfordian, northeastern France). Sedimentary Geology, 197, 235-266.
Carpentier, C., Martin-Garin, B., Lathuiliere, B., \& Ferry, S. (2006). Correlation of reefal Oxfordian episodes and climatic implications in the eastern Paris Basin (France). Terra Nova, 18, 191-201.

Cecca, F., Martin-Garin, B., Marchand, D., Lathuiliere, B., \& Bartolini, A. (2005). Paleo- climatic control of biogeographic and sedimentary events in Tethyan and peri-Tethyan areas during the Oxfordian (Late Jurassic). Palaeogeography, Palaeoclimatology, Palaeoecology, 222, 10-32.

Chevallier, T. (1989). Les formations carbonatées de la séquence ptérocérienne (Kimméridgien pars.) dans le Jura français et les régions voisines. Ph.D. dissertation, Institut Catholique de Lyon, Lyon (pp. 194).

Cochet, F. (1995). Stratigraphie séquentielle dans les carbonates de l'Oxfordien terminal-Kimméridgien du Jura français. Ph.D. dissertation, Université Claude Bernard Lyon 1, Villeurbanne, France (pp. 200).

Cochet, F., Ferry, S., Enay, R., \& Contini, D. (1994). Passage Oxfordien-Kimméridgien dans les carbonates du Jura français au Bassin vocontien. Régression forcée et cortège transgressif. Comptes Rendus de l'Académie des Sciences, série II, 319, 1041-1047.

Colombié, C. (2002). Sédimentologie, stratigraphie séquentielle et cyclostratigraphie du Kimméridgien du Jura suisse et du Bassin vocontien (France): relations plate-forme-bassin et facteurs déterminants. Ph.D. dissertation, Université de Fribourg, Suisse, GeoFocus, 4 (pp. 198).

Colombié, C., \& Rameil, N. (2007). Tethyan-to-boreal correlation in the Kimmeridgian using high-resolution sequence stratigraphy (Vocontian Basin, Swiss Jura, Boulonnais, Dorset). International Journal of Earth Sciences, 96, 567-591.

Colombié, C., \& Strasser, A. (2005). Facies, cycles, and controls on the evolution of a keep-up carbonate platform (Kimmeridgian, Swiss Jura). Sedimentology, 52, 1207-1227.

Comment, G., Ayer, J., \& Becker, D. (2011). Deux nouveaux membres lithostratigraphiques de la Formation de Reuchenette (Kimméridgien, Ajoie, Jura suisse) -- Nouvelles données géologiques et paléontologiques acquises dans le cadre de la construction de l'autoroute A16 (Transjurane). Swiss Bulletin für angewandte Geologie, 16, 3-24.

Contini, D., \& Hantzpergue, P. (1973). Le Kimméridgien de la région de Montbéliard. Annales scientifiques de l'Université de Besançon, 3, 143-179.

Contini, D., \& Hantzpergue, P. (1975). Le Kimméridgien de HauteSaône. Annales scientifiques de l'Université de Besançon, 3, 5-37.

Dera, G., Brigaud, B., Monna, F., Laffont, R., Puceat, E., Deconinck, J. F., et al. (2011). Climatic ups and downs in a disturbed Jurassic world. Geology, 39, 215-218.

Dercourt, J., LE Ricou, \& Vrielynck, B. (1993). Atlas of Tethys Palaeoenvironmental Maps (p. 307). Paris: Gauthier-Villars.

Donnadieu, Y., Dromart, G., Godderis, Y., Puceat, E., Brigaud, B., Dera, G., Dumas, C., \& Olivier, N. (2011). A mechanism for brief glacial episodes in the Mesozoic greenhouse. Paleoceanography, 26, PA3212. doi:10.1029/2010PA002100.

Dromart, G., Garcia, J.-P., Gaumet, F., Picard, S., Rousseau, M., Atrops, F., et al. (2003a). Perturbation of the carbon cycle at the Middle/Late Jurassic transition: geological and geochemical evidence. The Journal of American Science, 303, 667-707.

Dromart, G., Garcia, J.-P., Picard, S., Atrops, F., Lécuyer, C., \& Sheppard, S. M. F. (2003b). Ice age at the Middle-Late Jurassic transition? Earth Planetary Science Letters, 213, 205-220.

Dunham, R. J. (1962). Classification of carbonate rocks according to depositional texture. In W. E. Ham (Ed.), Classification of carbonate rocks-A symposium, American Association of Petroleum Geologists memoir, 1, (pp. 108-121). 
Dupraz, C., \& Strasser, A. (1999). Microbialites and micro-encrusters in shallow coral bioherms (Middle to Late Oxfordian, Swiss Jura Mountains). Facies, 40, 101-129.

Enay, R. (1966). L'Oxfordien dans la moitié sud du Jura français. Etude stratigraphique (pp. 624). Lyon: Nouvelles Archives du Muséum d'histoire naturelle de Lyon, 8.

Enay, R. (2000). Une faune d'ammonites inédite du Kimméridgien inférieur à Molinges (Jura) et la limite Oxfordien-Kimméridgien dans le faisceau externe du Jura méridional. Géologie de la France, 4, 3-19.

Enay, R. (2002). Réponse au commentaire de P. Bernier à la note : "Une faune d'ammonites inedited du Kimméridgien inférieur à Molinges (Jura) et la limite Oxfordien-Kimméridgien dans le faisceau externe du Jura méridional”, par R. Enay. Géologie de la France, 3, 62-63.

Enay, R., Contini, D., \& Boullier, A. (1988). Le Séquanien-type de Franche-Comté (Oxfordien supérieur): datations et corrélations nouvelles, conséquences sur la paléogéographie et l'évolution du Jura et régions voisines. Eclogae Geologicae Helvetiae, 81, 295-363.

Frakes, L. A., Francis, J. E., \& Syktus, J. I. (1992). Climate modes of the Phanerozoic. Cambridge: Cambridge University Press. 274 $\mathrm{pp}$.

Gaillard, C. (1983). Les biohermes à Spongiaires et leur environnement dans l'Oxfordien du Jura méridional. Documents du Laboratoire de Géologie de Lyon, 90 (pp. 515). Université Lyon 1, Lyon.

Görög, Á., \& Wernli, R. (2013). Protoglobigerinids of the Early Kimmeridgian of the Jura Mountains (France). Journal of Foraminiferal Research, 43, 280-290.

Gygi, R. A. (1986). Eustatic sea-level changes of the Oxfordian (Late Jurassic) and their effects documented in sediments and fossil assemblages of an epicontinental sea. Eclogae Geologicae Helvetiae, 79, 455-491.

Gygi, R. A. (2000). Integrated stratigraphy of the Oxfordian and Kimmeridgian (Late Jurassic) in northern Switzerland and adjacent southern Germany. Denkschriften der Schweizerischen Akademie der Naturwissenschaften, 104, (pp. 152).

Gygi, R. A., Coe, A. L., Vail, P. R. (1998). Sequence stratigraphy of the Oxfordian and Kimmeridgian stages (Late Jurassic) in northern Switzerland. In P.-C. de Graciansky, J. Hardenbol, T. Jacquin, \& P. R. Vail (Eds.), Mesozoic and Cenozoic Sequence Stratigraphy of European Basins, Soc. Econ. Paleontol. Mineral., Spec. Publ., 60, (pp. 527-544).

Gygi, R. A., \& Persoz, F. (1986). Mineralostratigraphy, litho- and biostratigraphy combined in correlation of the Oxfor- dian (Late Jurassic) formations of the Swiss Jura range. Eclogae Geologicae Helvetiae, 79, 385-454.

Halfar, J., Godinez-Orta, L., Mutti, M., Valdez-Holguin, J. E., \& Borges, J. M. (2006). Carbonates calibrated against oceanographic parameters along a latitudinal transect in the Gulf of California, Mexico. Sedimentology, 53, 297-320.

Hallam, A., Crame, J. A., Mancenido, M. O., Francis, J., \& Parrish, J. T. (1993). Jurassic Climates as Inferred from the Sedimentary and Fossil Record [and Discussion]. Phil. Trans. R. Soc. Lond. B, 28(341), 287-296.

Halley, R. B., Harris, P. M., \& Hine, A. C. (1983). Bank margin environment. In P. A. Scholle, D. G. Bebout, \& C. H. Moore (Eds.), Carbonate depositional environments, American Association of Petroleum Geologists Memoir, 33 (pp. 464-506).

Hallock, P., \& Schlager, W. (1986). Nutrient excess and the demise of coral reefs and carbonate platforms. Palaios, 1, 389-398.

Hantzpergue, P. (1975). Le Kimmeridgien à Céphalopodes du Jura méridional, Stratigraphie et Paléontologie. Ph.D. dissertation (pp. 285). Université Claude Bernard Lyon 1, Villeurbanne, France.
Hardenbol, J., Thierry, J., Farley, M. B., de Graciansky, P. C., \& Vail, P. R. (1998). Mesozoic and Cenozoic sequence chronostratigraphic framework of European basins. In P. C. de Graciansky, J. Hardenbol, T. Jacquin, \& P. R. Vail (Eds.), Mesozoic and Cenozoic sequence stratigraphy of European basins, SEPM Spec Publ, 60 (pp. 3-13).

Hug, W. A. (2003). Sequenzielle Faziesentwicklung der Karbonatplattform des Schweizer Jura im Späten Oxford und frühesten Kimmeridge. Ph.D. dissertation, GeoFocus, 7 (pp. 156). Université de Fribourg, Fribourg, Suisse.

Jank, M., Andreas, W., \& Christian, A. M. (2006a). A calibrated composite section for the Late Jurassic Reuchenette Formation in northwestern Switzerland (?Oxfordian, Kimmeridgian sensu gallico, Ajoie-Region). Eclogae Geologicae Helvetiae, 9, 175-191.

Jank, M., Meyer, C. A., \& Wetzel, A. (2006b). Late Oxfordian to Late Kimmeridgian carbonate deposits of NW Switzerland (Swiss Jura): Stratigraphical and palaeogeographical implications in the transition area between the Paris Basin and the Tethys. Sedimentary Geology, 186, 237-263.

Jank, M., Wetzel, A., \& Meyer, C. A. (2006c). Late Jurassic sea-level fluctuations in NW Switzerland (Late Oxfordian to Late Kimmeridgian): closing the gap between the Boreal and Tethyan realm in Western Europe. Facies, 52, 487-519.

Kiessling, W., Flügel, E., \& Golonka, J. (2003). Patterns of Phanerozoic carbonate platform sedimentation. Lethaia, 36, 195-225.

Lees, A. (1975). Possible influence of salinity and temperature on modern shelf carbonate sedimentation. Marine Geology, 19, $159-198$.

Lefort, A. (2011). La limite Oxfordien-Kimméridgien (Jurassique supérieur): stratigraphie et paléoenvironnements dans les domaines téthysien (Est et Sud du bassin de Paris, France) et boréal (Ile de Skye, Ecosse). Ph.D. dissertation (pp. 304). Université Henry Poincaré, Nancy, France.

Lefort, A., Lathuilière, B., Carpentier, C., \& Huault, V. (2011). Microfossil assemblages and relative sea-level fluctuations in a lagoon at the Oxfordian/Kimmeridgian boundary (Upper Jurassic) in the eastern part of the Paris Basin. Facies, 57, 649-662.

Leinfelder, R. R. (1993). A sequence stratigraphic approach of the Upper Jurassic mixed carbonate-siliclastic succession of the central Lusitanian Basin, Portugal. Profil, 5, 119-140.

Leinfelder, R., Schlagintweit, F., Werner, W., Ebli, O., Nose, M., Schmid, D., \& Hughes, G. (2005). Significance of stromatoporoids in Jurassic reefs and carbonate platforms - concepts and implications. Facies, 51, 288-326.

Leinfelder, R. R., Schmid, D. U., Nose, M., \& Werner, W. (2002). Jurassic reef patterns-the expression of a changing globe. In W. Kiessling, E. Flügel, \& J. Golonka, (Eds.), Phanerozoic Reef Patterns, SEPM Spec. Publ., 72 (pp. 465-520).

Martin-Garin, B., Lathuilière, B., Geister, J., \& Ramseyer, K. (2010). Oxygen isotopes and climatic control of Oxfordian coral reefs (Jurassic, Tethys). Palaios, 25, 721-729.

Mutti, M., \& Hallock, P. (2003). Carbonate systems along nutrient and temperature gradients: some sedimentological and geochemical constraints. International Journal of Earth Sciences, $92,465-475$.

Olivier, N., Colombié, C., Pittet, B., \& Lathuilière, B. (2011). Microbial carbonates and corals on the marginal French Jura platform (Late Oxfordian, Molinges section). Facies, 57, 469-492.

Olivier, N., Martin-Garin, B., Colombié, C., Cornée, J.-J., Giraud, F., Schnyder, J., et al. (2012). Ecological succession evidence in an Upper Jurassic coral reef system (Izwarn section, High Atlas, Morocco). Geobios, 45, 555-572. 
Pittet, B. (1996). Contrôles climatiques, eustatiques et tectoniques sur des systèmes mixtes carbonates-siliciclastiques de plate-forme: exemples de l'Oxfordien (Jura Suisse, Normandie, Espagne). Ph.D. dissertation (pp. 258). Université de Fribourg, Suisse.

Pittet, B., \& Strasser, A. (1998). Long-distance correlations by sequence stratigraphy and cyclostratigraphy; examples and implications (Oxfordian from the Swiss Jura, Spain, and Normandy). Geologische Rundschau, 86, 852-874.

Pittet, B., Strasser, A., \& Mattioli, E. (2000). Depositional sequences in deep-shelf en- vironments: a response to sea-level changes and shallow-platform carbonate productivity (Oxfordian, Germany and Spain). Journal of Sediment Research, 70, 392-407.

Reinhold, C. (1998). Multiple episodes of dolomitization and dolomite recrystallization during shallow burial in Upper Jurassic shelf carbonates: eastern Swabian Alb, southern Germany. Sedimentary Geology, 121, 71-95.

Riboulleau, A., Baudin, F., Daux, V., Hantzpergue, P., Renard, M., \& Zakharov, V. (1998). Evolution de la paléotempérature des eaux de la plate-forme russe au cours du Jurassique supérieur. Comptes Rendus de l'Académie des Sciences-Sciences de la Terre et des Planètes, 326 (pp. 239-246).

Schmid, D. U., \& Leinfelder, R. R. (1996). The Jurassic Lithocodium aggregatum-Troglotella incrustans foraminiferal consortium. Palaeontology, 39, 21-52.

Shiraishi, F., \& Kano, A. (2004). Composition and spatial distribution of microencrusters and microbial crusts in upper Jurassiclowermost Cretaceous reef limestone (Torinosu Limestone, southwest Japan). Facies, 50, 217-227.

Strasser, A. (1984). Black-pebble occurrence and genesis in Holocene carbonate sediments (Florida Keys, Bahamas, and Tunisia). Journal of sedimentary petrology, 54, 1097-1109.

Strasser, A. (1986). Ooids in Purbeck limestones (lowermost Cretaceous) of the Swiss and French Jura. Sedimentology, 33, 711-727.

Strasser, A. (1994). Milankovitch cyclicity and high-resolution sequence stratigraphy in lagoonal-peritidal carbonates (Upper Tithonian-Lower Berriasian, French Jura Mountains). In: P. L. de Boer, \& D. G. Smith (Eds.), Orbital Forcing and Cyclic Sequences. Spec. Publ. Int. Assoc. Sedimentol. 19 (pp. 285-301).
Strasser, A. (2007). Astronomical time scale for the Middle Oxfordian to Late Kimmeridgian in the Swiss and French Jura Mountains. Swiss Journal of Geosciences, 100, 407-429.

Strasser, A., Hillgärtner, H., Hug, W., \& Pittet, B. (2000). Third-order depositional sequences reflecting Milankovitch cyclicity. Terra Nova, 12, 303-311.

Strasser, A., Pittet, B., Hillgaertner, H., \& Pasquier, J. B. (1999). Depositional sequences in shallow carbonate-dominated sedimentary systems; concepts for a high-resolution analysis. Sedimentary Geology, 128, 201-221.

Strasser, A., Védrine, S., \& Stienne, N. (2012). Rate and synchronicity of environmental changes on a shallow carbonate platform (Late Oxfordian, Swiss Jura Mountains). Sedimentology, 59, 185-211.

Thierry, J., \& 41, co-auteurs. (2000). Early Kimmeridgian (146-144 Ma). Map 10. In: J. Dercourt, M. Gaetani, B. Vrielynck, et al. (Eds.), Atlas Peri-Tethys. Palaeogeographical Maps (pp. 85-97).

Tucker, M. E., \& Wright, V. P. (1990). Carbonate Sedimentology Blackwell (pp. 482). Oxford.

Védrine, S. (2007). High-frequency palaeoenvironmental changes in mixed carbonate-siliciclastic sedimentary systems (Late Oxfordian, Switzerland, France, and southern Germany). Ph.D. dissertation, GeoFocus, 19 (pp. 216). Université de Fribourg Fribourg, Suisse.

Védrine, S., Strasser, A., \& Hug, W. (2007). Oncoid growth and distribution controlled by sea-level fluctuations and climate (Late Oxfordian, Swiss Jura Mountains). Facies, 53, 535-552.

Wetzel, A., Allenbach, R., \& Allia, V. (2003). Reactivated basement structures affecting the sedimentary facies in a tectonically "quiescent" epicontinental basin; an example from NW Switzerland. Sedimentary Geology, 157, 153-172.

Wright, V. P., \& Burchette, T. P. (1996). Shallow-water carbonate environments. In H. G. Reading (Ed.), Sedimentary Environments: Processes, Facies and Stratigraphy (3rd ed., pp. 325-394). London: Blackwell. 